\title{
Effect of Dietary Supplemental Ginger on Broiler Performance, Carcass Characteristics and Blood Profile
}

\section{Rasha I. Hassan ${ }^{\text {* }}$, Gamal M. Mosaad ${ }^{1}$, Hala Y. Abd El-wahab ${ }^{2}$}

${ }^{1}$ Department of Animal Nutrition and Clinical Nutrition, Faculty of Veterinary Medicine, Assiut University, Egypt. ${ }^{2}$ Department of Animal Nutrition and Clinical Nutrition, Faculty of Veterinary Medicine, New Valley University, Egypt

\section{Abstract}

A study using one hundred unsexed day-old broiler chicks (Ross 308), 25 birds/treatment was conducted to evaluate the effect of ginger powder as natural feed additives on the growth performance, carcass traits and blood parameters of broiler chickens. Four dietary treatments were formulated to meet the nutrient requirements of broiler chicks containing ginger powder at levels $0 \%, 0.2 \%, 0.4 \%$ and $0.6 \%$. The results showed that no significant differences were recorded in body weight and body weight gain between different experimental groups. Birds fed diets supplemented with ginger exhibited better feed conversion $(\mathrm{P}>0.05)$ and lower feed intake than control birds. The measurements of carcass traits, hematological values and serum biochemical parameters showed no marked variation between the treated groups. It could be concluded that ginger powder at the used levels in this experiment has not potential to be used as a growth promoter in broiler chicks.

Keywords: Ginger, Growth performance, Carcass traits, Blood parameters, Broilers

DOI: $10.21608 / \mathrm{svu} .2019 .6404 .1000$

Received: January 15, $2019 \quad$ Accepted: March 15, $2019 \quad$ Published: March 23, 2019 *Corresponding Author: Rasha I. Hassan E-mail: rasha_feeding@yahoo.com Citation: Hassan et al., 2019. Effect of Dietary Supplemental Ginger on Broiler Performance, Carcass Characteristics and Blood Profile. SVU-IJVS 2019, 2 (1):108-118.

Copyright: (C) This is an open access article distributed under the terms of the creative common attribution license, which permits unrestricted use, distribution and reproduction in any medium provided the original author and source are created.

Competing interest: The authors have declared that no competing interest exists. 


\section{Introduction}

Feed additives are nutritive and nonnutritive compounds that are included in poultry ration to improve feed efficiency and weight gain in broilers (Fadlalla et al., 2010, Abouelfetouh and Moussa, 2012, Al-Mashhadani, 2014, Mohamed et al., 2018). In the past, antibiotics were the most commonly used feed additives. However, these days the use of antibiotics have been prohibited in many countries due to their effect on natural gut microflora and drug resistance in humans. As a result, to substitute them without country affecting the health and performance of birds, natural growth promoters such as probiotics, prebiotics, symbiotic, organic acids, enzymes, antioxidants, pellet-binder, herbs and spices can be used (Zhang et al., 2009, Karangiya et al., 2016). Herbs are used worldwide to mitigate or treat illness and elevate the overall wellness. Estimated $60 \%$ of world's use herbal as a remedy (Astin, 1998). Herbs and spices and their constituents are generally known to be safe and being an opulent source of secondary bimolecular which exhibit considerable pharmacological impacts (Craig, 1999). Ginger is the rhizome of the plant Zingiber officinale, consumed as a medicine, delicacy or spice. The main remarkable components in ginger are gingerdione, gingerdiol and gingerol, which when used in broiler diets have the ability to activate digestive enzymes and affect the microbial activity (Dieumou et al., 2009). The active compounds in ginger have been reported to possess antioxidant, antimicrobial, Immuno-modulatory, anti-tumorigenic, anti-inflammatory, anti-apoptotic, antihyperglycemic, anti-lipidemic and antiemetic properties (Al-Amin et al., 2006, Ali et al., 2008, Morakinyo et al., 2011). Therefore, the present research was conducted to evaluate the growth performance, carcass composition, serum biochemical parameters and hematology of broilers fed diets containing different levels of ginger as feed additive up to 42 days of age.

\section{Materials and methods \\ Experimental birds and diets}

A Total of one hundred one day old (Ross 308) broiler chicks were purchased from local hatchery and randomly distributed into four groups, each of 25 . A basal starter and finishing diets were in mash form and formulated to meet the nutrient requirement guidelines of National Research Council (1994). The experimental groups were as follows: T1: control, T2:2.0 g ginger $/ \mathrm{kg}$ ), T3:4.0 g ginger $/ \mathrm{kg}$ ) and T4: $6.0 \mathrm{~g}$ ginger $/ \mathrm{kg}$ ). The ginger was purchased from the local herbal market as a powder. The birds were fed with starter diet until 21 days of age, followed by finishing diet until 42 days of age. Feed and water were provided for ad libitum consumption. Birds were vaccinated against infectious bronchitis, Newcastle and Gambaro diseases, but no medications were administered during the whole experimental period. All the chickens were maintained at a symmetric temperature and lighting control programme during the whole study period.

\section{Measurements}

\section{Performance and carcass traits}

Body weights of the chicks were measured at 1, 7, 15, 28, 35and 42 days and average daily feed intake was determined for different experimental periods. Feed conversion ratio was calculated as feed intake: body weight gain at the end of each experimental period. At the end of the experiment, three birds from each group were randomly chosen, slaughtered and the carcass weight, the edible inner organs (heart, liver, gizzard) and lymphoid organs (spleen, thymus and bursa of Fabricius) were weighed and expressed as a percentage of live body weight.

\section{Haematological parameters and blood leucocyte profiles}

To evaluate the effects of different dietary treatments on blood haematology at 42 days, blood samples were collected from three birds in each treatment into 
EDTA-anticoagulant treated vials. The red blood cell (RBC) and white blood cell (WBC) counts were determined by a haemocytometer method using Natt Herrick solution; haematocrit and haemoglobin values were measured by microhaematocrit and

cyanmethaemoglobin methods respectively (Kececi et al., 1998). To determine the leucocyte profiles, one hundred leucocytes per samples were counted by an optical microscope for heterophil to lymphocyte separation according to the protocol described by Lucas and Jamroz (1961).

\section{Serum biochemistry}

At 35 days of the experiment, $2 \mathrm{ml}$ of blood was collected from the brachial vein from three birds from each group to obtain serum by centrifugation at 3000 rpm for 15 minutes. Serum samples were assayed for estimation of total protein, albumin, globulin and uric acid by spectrophotometer using commercial test kits (Spectrum, Cairo, Egypt).

\section{Statistical analysis}

The collected data was analyzed by one-way ANOVA procedure using the statistical computer Program SPSS 16.00 Software (SPSS Inc., Chicago, IL, USA). Means were compared by Duncan's test when a significant difference was found.

Table (1) : Dietary composition of experimental starter and finisher broiler diets

\begin{tabular}{|c|c|c|}
\hline Ingredients \% & $\begin{array}{c}\text { Starter Diet } \\
(1-21 \text { days })\end{array}$ & $\begin{array}{c}\text { Finisher } \\
\text { Diet } \\
(22-42 \\
\text { days })\end{array}$ \\
\hline Yellow corn & 54.53 & 61.37 \\
\hline Soya Bean meal & 36.96 & 31.59 \\
\hline Sun Flower oil & 4.83 & 3.85 \\
\hline Lime stone, ground & 1.20 & 1.29 \\
\hline $\begin{array}{c}\text { Dicalcium } \\
\text { phosphate }\end{array}$ & 1.74 & 1.26 \\
\hline Salt & 0.30 & 0.30 \\
\hline Methionine & 0.14 & 0.04 \\
\hline Premix* & 0.30 & 0.30 \\
\hline Total & 100 & 100 \\
\hline
\end{tabular}

\begin{tabular}{|c|c|c|}
\hline Calculated analysis & & \\
\hline Kcal ME/Kg diet & 3195 & 3199 \\
\hline Crude protien \% & 22.92 & 20.99 \\
\hline Calcium \% & 1.00 & 0.90 \\
\hline $\begin{array}{c}\text { Phosphorus } \\
\text { available \% }\end{array}$ & 0.45 & 0.35 \\
\hline Methionine & 0.50 & 0.38 \\
\hline Lysine & 1.32 & 1.16 \\
\hline
\end{tabular}

*Each3 kg contains: Vit. A, 1200000 IU; Vit. $\mathrm{D}_{3}, 300000 \mathrm{IU}$; Vit. E, $700 \mathrm{mg}$; Vit. $\mathrm{k}_{3}, 500$ mg; Vit. $B_{1}, 500 \mathrm{mg}$; Vit. $\mathrm{B}_{2}, 200 \mathrm{mg}$; Vit. $\mathrm{B}_{6}, 600 \mathrm{mg}$; Vit. $\mathrm{B}_{12}, 3 \mathrm{mg}$; Vit. C, $450 \mathrm{mg}$; Niacin, $3000 \mathrm{mg}$; Methionine, $3000 \mathrm{mg}$; Pantothenicacid, $670 \mathrm{mg}$; Folicacid $300 \mathrm{mg}$; Biotin, $6 \mathrm{mg}$; Choline chloride, $10000 \mathrm{mg}$; Magnesiumsulphate, $3000 \mathrm{mg}$; Copper sulphate, $3000 \mathrm{mg}$;Ironsulphate, $10000 \mathrm{mg}$; Zinc sulphate, $1800 \mathrm{mg}$; Cobalt sulphate,300 mg.

\section{Results}

The effect of ginger on body weight and weight gain of broilers chicks are presented in Table $2 \& 3$. The obtained results indicated that, inclusion of ginger in broiler diets had no significant effect on body weight and gain throughout the whole study period. The highest body weight $(2150 \mathrm{~g})$ were observes in T2 group compared to control $(2132 \mathrm{~g})$. The obtained results (Table 4) cleared that, feeding ginger to broilers numerically decrease the total feed intake compared to the control group. The feed intake appeared to be the lowest $(\mathrm{P}>0.05)$ on diet with $0.6 \%$ ginger. Regarding the effect of dietary inclusion of ginger on feed conversion ratio (FCR) of broilers during the experiment (Table 5), the obtained results indicated that, the supplementation of ginger in the diet of broiler chickens does not exert any significant effect on FCR as compared to control. Although, better FCR was observed in T3 group followed by T4 and T2 groups. The effect of ginger on carcass traits of broilers is presented in Table 6. The obtained data revealed that, there were no significant differences in live weight, dressing weight and percentage and relative weights of liver, heart, gizzard, spleen, bursa of Fabricius and thymus between different 
treated groups. Data presented in table 7 showed that, no significant differences were recorded in the average values of hematological indices and serum biochemical parameters between different experimental groups.

Table (2): Effect of dietary ginger powder on body weight ( $\mathrm{g}$ ) of broilers

\begin{tabular}{|c|c|c|c|c|}
\hline \multirow{2}{*}{$\begin{array}{c}\text { Exp. } \\
\text { period } \\
\text { (week) }\end{array}$} & \multicolumn{4}{|c|}{ Treatments } \\
\cline { 2 - 5 } & Control group & $\mathrm{T} 1$ & $\mathrm{~T} 2$ & $\mathrm{~T}$ \\
\hline & $51.80 \pm 1.39$ & $51.75 \pm 1.47$ & $52.27 \pm 1.35$ & $51.08 \pm 0.92$ \\
\hline $\mathbf{I n i t i a l}$ & $197.13 \pm 4.62$ & $195.08 \pm 6.70$ & $195.85 \pm 2.60$ & $195.91 \pm 5.61$ \\
\hline $\mathbf{1}$ & $474.13 \pm 11.88$ & $473.49 \pm 12.51$ & $466.93 \pm 9.99$ & $456.82 \pm 22.90$ \\
\hline $\mathbf{2}$ & $918.05 \pm 22.83$ & $914.74 \pm 16.28$ & $895.76 \pm 23.06$ & $912.82 \pm 38.84$ \\
\hline $\mathbf{3}$ & $1362.63 \pm 35.60$ & $1363.90 \pm 31.43$ & $1359.92 \pm 48.73$ & $1393.32 \pm 45.50$ \\
\hline $\mathbf{4}$ & $1760.13 \pm 53.36$ & $1772.06 \pm 67.24$ & $1783.00 \pm 49.10$ & $1743.90 \pm 78.45$ \\
\hline $\mathbf{5}$ & $2131.80 \pm 64.40$ & $2149.66 \pm 111$ & $2133.00 \pm 66.93$ & $2125.56 \pm 1.05$ \\
\hline $\mathbf{6}$ & & &
\end{tabular}

T1: control, T2: basal diet plus $0.2 \%$ of ginger powder, T3: basal diet plus $0.4 \%$ of ginger powder, T4: basal diet plus $0.6 \%$ of ginger powder.

Table (3): Effect of dietary ginger powder on weight gain (g) of broilers

\begin{tabular}{|c|c|c|c|c|}
\hline \multirow{2}{*}{$\begin{array}{c}\text { Exp. } \\
\text { period } \\
\text { (week) }\end{array}$} & \multicolumn{4}{|c|}{ Treatments } \\
\cline { 2 - 5 } & Control group & $\mathrm{T} 2$ & $\mathrm{~T} 3$ & $\mathrm{~T} 4$ \\
\hline $\mathbf{1}$ & $145.33 \pm 3.22$ & $143.33 \pm 5.88$ & $143.58 \pm 1.16$ & $144.83 \pm 5.23$ \\
\hline $\mathbf{2}$ & $277.00 \pm 11.11$ & $278.41 \pm 12.59$ & $271.08 \pm 9.58$ & $260.91 \pm 23.91$ \\
\hline $\mathbf{3}$ & $443.92 \pm 12.98$ & $441.25 \pm 5.12$ & $428.83 \pm 13.84$ & $456.00 \pm 44.09$ \\
\hline $\mathbf{4}$ & $444.58 \pm 23.06$ & $449.16 \pm 46.71$ & $464.16 \pm 43.68$ & $480.50 \pm 21.78$ \\
\hline $\mathbf{5}$ & $397.50 \pm 21.69$ & $408.16 \pm 26.87$ & $423.08 \pm 37.32$ & $350.58 \pm 64.23$ \\
\hline $\mathbf{6}$ & $371.67 \pm 16.61$ & $377.60 \pm 41.04$ & $350.00 \pm 28.05$ & $381.66 \pm 17.41$ \\
\hline
\end{tabular}


Table (4): Effect of dietary ginger powder on feed intake (g) of broilers

\begin{tabular}{|c|c|c|c|c|}
\hline \multirow{2}{*}{$\begin{array}{c}\text { Exp. } \\
\text { period } \\
\text { (week) }\end{array}$} & \multicolumn{4}{|c|}{ Treatments } \\
\cline { 2 - 5 } & Control group & T2 & T3 & T4 \\
\hline $\mathbf{1}$ & 190.38 & 193.50 & 195.27 & 207.11 \\
\hline $\mathbf{2}$ & 498.60 & 523.41 & 485.23 & 495.73 \\
\hline $\mathbf{3}$ & 834.57 & 745.71 & 746.16 & 898.32 \\
\hline $\mathbf{4}$ & 978.08 & 1190.27 & 1197.53 & 879.32 \\
\hline $\mathbf{5}$ & 1077.23 & 1053.05 & 1049.24 & 978.12 \\
\hline $\mathbf{6}$ & 1040.68 & 928.90 & 822.50 & 1003.77 \\
\hline Total & 4619.54 & 4634.84 & 4495.93 & 4462.37 \\
\hline
\end{tabular}

Table (5): Effect of dietary ginger powder on feed conversion ratio of broilers

\begin{tabular}{|c|c|c|c|c|}
\hline \multirow{2}{*}{$\begin{array}{c}\text { Exp. } \\
\text { period } \\
\text { (week) }\end{array}$} & \multicolumn{4}{|c|}{ Treatments } \\
\cline { 2 - 5 } & Control group & $\mathrm{T} 2$ & $\mathrm{~T} 3$ & $\mathrm{~T} 4$ \\
\hline $\mathbf{1}$ & $\mathrm{T} 1$ & 1.35 & 1.36 & 1.43 \\
\hline $\mathbf{2}$ & 1.31 & 1.88 & 1.79 & 1.90 \\
\hline $\mathbf{3}$ & 1.80 & 1.69 & 1.74 & 1.97 \\
\hline $\mathbf{4}$ & 2.20 & 2.65 & 2.58 & 1.83 \\
\hline $\mathbf{5}$ & 2.71 & 2.58 & 2.48 & 2.79 \\
\hline $\mathbf{6}$ & 2.80 & 2.46 & 2.35 & 2.63 \\
\hline Average & $2.11 \pm 0.23$ & $2.10 \pm 0.21$ & $2.05 \pm 0.19$ & $2.09 \pm 0.21$ \\
\hline
\end{tabular}


Table (6): Effect of dietary ginger powder on carcass traits of broilers

\begin{tabular}{|c|c|c|c|c|}
\hline \multirow{2}{*}{ Parameters } & \multicolumn{4}{|c|}{ Treatments } \\
\cline { 2 - 5 } & Control group & \multicolumn{3}{|c|}{ Ginger groups } \\
\cline { 2 - 5 } & $\mathrm{T} 1$ & $\mathrm{~T} 2$ & $\mathrm{~T} 3$ & $\mathrm{~T} 4$ \\
\hline liver weight (g) & $2150.00 \pm 0.28$ & $2195.00 \pm 0.06$ & $2116.70 \pm 0.11$ & $2293.30 \pm 0.06$ \\
\hline Dressing weight, g & $1585.34 \pm 50.81$ & $1631.50 \pm 113.35$ & $1580.12 \pm 109.94$ & $1750.12 \pm 29.02$ \\
\hline Dressing (\%) & $73.48 \pm 5.26$ & $74.10 \pm 3.40$ & $74.65 \pm 1.02$ & $73.32 \pm 0.81$ \\
\hline Liver (\%) & $1.99 \pm 0.11$ & $1.83 \pm 0.23$ & $1.91 \pm 0.03$ & $1.83 \pm 0.13$ \\
\hline Heart (\%) & $0.44 \pm 0.06$ & $0.39 \pm 0.07$ & $0.53 \pm 0.04$ & $0.55 \pm 0.07$ \\
\hline Gizzard (\%) & $1.63 \pm 0.04$ & $1.62 \pm 0.44$ & $1.58 \pm 0.09$ & $1.72 \pm 0.11$ \\
\hline $\begin{array}{c}\text { Spleen (\%) } \\
\text { Bursa of Fabricius } \\
(\%)\end{array}$ & $0.09 \pm 0.02$ & $0.13 \pm 0.001$ & $0.09 \pm 0.01$ & $0.12 \pm 0.001$ \\
\hline Thymus (\%) & $0.08 \pm 0.07$ & $0.09 \pm 0.01$ & $0.08 \pm 0.01$ & $0.09 \pm 0.03$ \\
\hline
\end{tabular}

Table (7): Effect of dietary ginger powder on hematological indices and serum biochemical response of broilers

\begin{tabular}{|c|c|c|c|c|}
\hline \multirow{2}{*}{ Item } & \multicolumn{4}{|c|}{ Treatments } \\
\cline { 2 - 5 } & Control group & $\mathrm{T} 2$ & $\mathrm{~T} 3$ & $\mathrm{~T} 4$ \\
\hline Haemoglobin (g/dl) & $7.80 \pm 0.53$ & $7.20 \pm 0.06$ & $7.57 \pm 0.17$ & $6.90 \pm 0.12$ \\
\hline WBCs (x10 $\left./ \mathbf{m m}^{\mathbf{3}}\right)$ & $12.23 \pm 0.64$ & $11.40 \pm 0.87$ & $11.57 \pm 0.77$ & $12.95 \pm 2.02$ \\
\hline RBCs (x106/mm3) & $4.43 \pm 0.24$ & $4.25 \pm 0.03$ & $4.40 \pm 0.15$ & $3.90 \pm 0.20$ \\
\hline PCV\% & $22.63 \pm 1.47$ & $20.95 \pm 0.14$ & $21.97 \pm 0.47$ & $20.15 \pm 0.32$ \\
\hline MCV (fl) & $71.10 \pm 0.59$ & $69.35 \pm 0.72$ & $70.10 \pm 1.36$ & $77.15 \pm 2.40$ \\
\hline MCH (pg) & $16.95 \pm 0.26$ & $17.60 \pm 0.26$ & $16.83 \pm 0.59$ & $18.20 \pm 0.78$ \\
\hline MCHC \% & $34.43 \pm 0.09$ & $34.35 \pm 0.03$ & $34.43 \pm 0.03$ & $34.25 \pm 0.03$ \\
\hline Heterophils\% & $20.50 \pm 3.60$ & $20.00 \pm 0.01$ & $23.33 \pm 2.67$ & $22.50 \pm 4.91$ \\
\hline Lymphocyte\% & $80.00 \pm 4.00$ & $77.00 \pm 1.44$ & $71.67 \pm 1.67$ & $76.50 \pm 4.91$ \\
\hline Monocyte\% & $10.00 \pm 1.00$ & $9.65 \pm 1.44$ & $11.25 \pm 1.00$ & $10.15 \pm 0.01$ \\
\hline Total protein g/dl & $5.84 \pm 0.55$ & $5.05 \pm 0.18$ & $5.67 \pm 0.30$ & $5.46 \pm 0.27$ \\
\hline Albumin g/dl & $3.89 \pm 0.14$ & $3.4 \pm 0.15$ & $3.57 \pm 0.21$ & $3.87 \pm 0.11$ \\
\hline Globulin g/dl & $1.95 \pm 0.41$ & $1.65 \pm 0.06$ & $2.10 \pm 0.15$ & $1.59 \pm 0.16$ \\
\hline Uric acid mg/dl & $48.00 \pm 0.80$ & $50.40 \pm 0.85$ & $49.39 \pm 0.56$ & $49.88 \pm 1.40$ \\
\hline
\end{tabular}




\section{Discussion}

The results of body weight and weight gain are consistent with those of Mohammed and Yusuf (2011), Bamidele and Adejumo (2012), Shanoon et al. (2012), Zomrawi et al. (2013), Ahmed et al. (2014) who did not observe any significant improvements in body weight and gain of broilers fed on a diet containing ginger powder as compared to the control group. However, AlMashhadani (2014), Ebrahimmezhad et al. (2014), Karangiya et al. (2016), Sadeghi and Moghaddam (2018) concluded that, inclusion of ginger in broiler diets had positive effect on the body weight and weight gain. Ademola et al. (2009), Zomrawi et al. (2012) stated that, inclusion of ginger in broiler diets has negative effect on body weight gain. The present results concerning the feed intake are agreed with those reported by Herawati and Marjuki (2011), Saleh et al. (2014) who recorded that, feed intake was decreased in birds fed ginger supplemented diets. Our results disagreed with that found by Onu and Aja (2011), Tekeli et al. (2011), Valiollahi et al. (2014) who reported that, ginger supplementation in broiler diets had a positive effect on feed consumption with respect to the control one. The decreasing in feed intake due to the higher level of ginger may be attributed to the adverse effect of taste of ginger on the feed palatability in the diets of broiler chickens. The insignificant improvement in FCR in this study may be attributed to that ginger has ability to increase the digestive and absorptive capacity of the small intestine of commercial broilers by increasing the cryptal depth as well as the intestinal absorptive surface area i.e. villi length and width (Karangiya et al., 2016). The results of FCR are in harmony with the results recorded by Moorthy et al. (2009), Herawati (2010), Sadeghi and Moghaddam (2018) who demonstrated that, inclusion of ginger in poultry diet had positive effect on feed conversion ratio. In addition, Wafaa et al. (2012), Fakhim et al. (2013) who reported that, inclusion of ginger in broiler diets did not exert any effect on FCR as compared to control. In contrast, Iqbal et al. (2011), Saleh et al. (2014) observed that, dietary inclusion of ginger increased the value feed conversion ratio compared to control one. In the present study, dietary inclusion of ginger had no marked effect on dressing percentage and the relative weight of internal organs. In agreement with our findings, Najafi and Torki (2010), Onu (2010), Rahimi et al. (2011), Habibi et al. (2014) noted that supplemental ginger in feed or drinking water for broilers chicken had no significant effect on dressing percentage and the relative weight of liver, heart and gizzard. Feeding on ginger reported no significant effect on the hematological indices. The same results were recorded by Nasiroleslami and Torki (2010), Habibi et al. (2014) who found that no effect of ginger on hematological parameters of broilers. However, ALMoramadhi (2010), Onu and Aja (2011) found that, inclusion of ginger in broiler diets significantly increased the hemoglobin concentration, packed cell volume and white blood cells.

The results of serum metabolites could be supported by the findings of Arkan et al. (2012), Mohamed et al. (2012) which revealed that, the serum protein, albumin, globulin and uric acid did not affect by inclusion of ginger in broiler diets. However, Rehman et al. (2011), Rafiee et al. (2013) reported that, inclusion of ginger in broiler diets increased the serum concentration of total protein, albumin and globulin.

\section{Conclusion}

It could be concluded that ginger powder at the levels used in this work has no significant effect on growth performance of broiler chicks. Ginger at the $0.6 \%$ level had no side effect on bird's health as detected by the normal physiological blood profile. Additionally, more studies should be proceeded to evaluate higher levels of ginger.

\section{References}


Abouelfetouh AY, Moussa NK (2012). Enhancement of antimicrobial activity of four classes of antibiotics combined with garlic. Asian Journal of Plant Sciences, 11(3): 148 .

Ademola SG, Farinu G, Babatunde GM (2009). Serum lipid, growth and hematological parameters of broilers fed garlic, ginger and their mixtures. World Journal of Agricultural Sciences, 5: 99-104.

Ahmed MH, Atti KAA, Malik HEE, Elamin KM,Dousa BM (2014). Ginger (Zingiberofficinale) root powder as natural feed additive for broiler chicks. Global Journal of Animal Scientific Research, 2 (4): 383-389.

Al-Amin ZM, Thomson M, Al-Qattan KK, PeltonenShalaby $\mathrm{R}$ and Ali $\mathrm{M}$ (2006). Anti-diabetic and hypolipidemic properties of ginger (Zingiberofficinale) in streptozotocin induced diabetic rats. British Journal of Nutrition, 96: 660-666.

Ali BH, Blunden G, Tanira MO, Nemmar A (2008). Some phytochemical, pharmacological and toxicological properties of ginger (ZingiberOfficinale Roscoe). A review of recent research. Food chemistry and toxicology, 46:409420.

Al-Mashhadani HE (2014). Effect of supplementing different levels of ginger, thyme and their mixture on broiler performance, carcass characteristics and bacterial count. Research Opinions in Animal and Veterinary Sciences, 4(12):689694.

Al-Moramadhi SAH (2010). The effect of Zingiber officinali roots infusion on some physiological parameters in broiler chickens. Kufa Journal for Veterinary Medical Sciences, 1(2): 67-76.

Arkan BM, Mohammed AM, Al-Rubaee, Ali QJ (2012).Effect of ginger (Zingiberofficinale) on performance and blood serum parameters of broiler. International Journal of Poultry Science, 11 (2): 143-146.

Astin JA (1998). Why patients use alternative medicine; results of a national study. Journal of Veterinary and Medical Association, 279: 1548- 1553.

Bamidele O, Adejumo IO (2012). Effect of garlic (Allium sativum L.) and ginger (Zingiber Officinale Roscoe) mixtures on performance characteristics and cholesterol profile of growing pullets. International Journal of Poultry Science, 11 (3): 217-220.

Craig WJ (1999). Health promoting properties of common herbs. American Journal of Clinical Nutrition, 70: 491- 499.

Dieumou FE, Teguia A, Kuiate JR, Tamokou JD, Fonge NB, Dongmo MC (2009). Effects of ginger (Zingiber Officinale) and garlic (Allium sativum) essential oils on growth performance and gut microbial population of broiler chickens. Livestock Research for Rural Development, 21: 25-34.

Ebrahimnezhad Y, Azarakhsh V, Salmanzadeh M (2014). The effects of ginger root (zingiber officiale) processed to different levels on growth performance, carcass characteristics and blood biochemistry parameters in broiler chickens. Bulletin of Environment, Pharmacology and Life Sciences, 3 (5):203-208. 
Fadlalla IMT, Mohammed BH, Bakhiet AO (2010). Effect of feeding garlic on the performance and immunity of broilers. Asian Journal of Poultry Science, 4(4): 182-189.

Fakhim R, Ebrahimnezhad Y, Seyedabadi HR, Vahdatpour T (2013). Effect of different concentrations of aqueous extract of ginger (Zingiber Officinale) on performance and carcass characteristics of male broiler chickens in wheat-soybean meal-based diets. Journal of Bioscience and Biotechnology, 2 (2): 95-99.

Habibi RI, Sadeghi G, Karimi A (2014). Effect of different concentrations of ginger root powder and its essential oil on growth performance, serum metabolites and antioxidant status in broiler chicks under heat stress. British poultry science, 55 (2):228-37.

Herawati and Marjuki (2011). Effect of feeding red ginger as phytobiotic on broiler slaughter weight and meat quality. International. Journal of Poultry Science, 10 (12): 983986.

Herawati O (2010). The effect of feeding red ginger as phytobiotic on body weight gain, feed conversion and internal organs condition to broiler.International Journal of Poultry Science, 9: 963-967.

Iqbal Z, Nadeem QK, Khan MN, Akhtar MS, Waraich FN (2011). In vitro anthelmintic activity of Allium sativum, Zingiber Officinale, Curcurbita Mexicana and Ficusreligiosa. International Journal of Agriculture biology, 3: 454-457.

Karangiya VK, Savsani HH, Patil SS, Garg DD, Murthy KS, Ribadiya NK, Vekariya SJ (2016). Effect of dietary supplementation of garlic, ginger and their combination on feed intake, growth performance and economics in commercial broilers. Veterinary world, 9(3): 245.

Kececi O, Oguz H, Kurtoglu V, Demet O (1998). Effects of polvinylpolypyrr-olidone, synthetic zeolite and bentonite on serum biochemical and haematological characters of broiler chickens during aflatoxicosis. British Poultry Science, 39: 452-458.

Lucas AM, Jamroz C (1961). Atlas of Avian Hematology. Agriculture Monograph 25. USDA, Washington, DC.

Mohamed, AB, Al-Rubaee, MAM, Jalil, AQ (2012). Effect of ginger (Zingiber Officinale) on performance and blood serum parameters of broiler. International Journal of Poultry Science, 11 (2):143-146.

Mohamed RI, Mosaad GM, El-wahab HYA (2018). Effect of feeding propolis on growth performance of broilers. Journal of Advanced Veterinary Research, 8(3):66-72.

Mohammed N, Yusuf M (2011). Evaluation of ginger (Zingiber Officinale) as a feed additive in broiler diets. Journal of Advanced Veterinary Research, 3: 14-17.

Moorthy M, Ravi S, Ravikumar MR, Viswanathan K, Edwin SC (2009). Ginger, pepper and curry leaf powder as feed additive in broiler diet. International Journal of Poultry Science, 8:779- 782.

Morakinyo AO, Akindele AJ and Ahmed, $\mathrm{Z}$ (2011). Modulation of antioxidant enzymes and inflammatory cytokines: Possible mechanism of anti-diabetic effect of ginger extracts. African Journal 
of Biomedical Research, 9: 195202.

Najafi P, Torki M (2010). Performance, blood metabolites and immunocompetence of broiler chicks fed diets induced essential oil of medicinal herbs. Journal of Animal and Veterinary Advances, 9: 1164-1168.

Nasiroleslami M, Torki M (2010). Including essential oils of fennel (Foeniculum Vulgare) and ginger (Zingiber Officinale) to diet and evaluating performance of laying hens, white blood cell count and egg quality characteristics. Advances in Environmental Biology, 4 (3): 341-345.

NRC (1994). Nutrient Requirements of Poultry 9 ${ }^{\text {th }}$ Revised Ed, National Academy of Sciences Press, Washington, D C, USA.

Onu PN, Aja PM (2011). Growth performance and hematological indices of weaned rabbits fed garlic (Allium sativum) and ginger (Zingiber Officinale) supplemented diets International Journal of Food, Agriculture and Veterinary Sciences, 1(1): 51-59.

Onu PN (2010). Evaluation of two herbal spices as feed additives for finisher broilers Biotechnology in Animal Husbandry, 26 (5-6): 383-392.

Rafiee A, Rahimian Y, Zamani F, Asgarian F (2013). Effect of use ginger (Zingiber Officinale) and thymus (Thymus vulgaris) extract on performance and some hematological parameters on broiler chicks. Scientia Agriculturae, 4 (1): 20-25.

Rahimi S, Zadeh ZT, Torshizi MAK, Omidbaigi R and Rokni, H (2011). Effect of the three herbal extracts on growth performance, immune system, blood factors and intestinal selected bacterial population in broiler chickens Journal of Agricultural Science Technology, 13: 527-539.

Rehman S, Durrani FR, Chand N, Khan RU, Rehman, FU (2011). Comparative efficacy of different schedules of administration of medicinal plants infusion on hematology and serum biochemistry of broilers. Research Opinions in Animal and Veterinary Sciences, 1: 8-14.

Sadeghi AA, Moghaddam M (2018). The effects of turmeric, cinnamon, ginger and garlic powder nutrition on antioxidant enzymes' status and hormones involved in energy metabolism of broilers during heat stress. Iranian Journal of Applied Animal Science, 8(1): 125-130.

Saleh N, Allam T, El-Latif AA, Ghazy E (2014). The effects of dietary supplementation of different levels of thyme (Thymus vulgaris) and ginger (Zingiber Officinale) essential oils on performance, hematological, biochemical and immunological parameters of broiler chickens. Global Veterinaria, 12 (6): 736-744.

Shanoon AK, Jassim MS, Amin QH,Ezaddin IN (2012).Effects of ginger (Zingiberofficinale) oil on growth performance and microbial population of broiler Ross 308.International Journal of Poultry Science, 11 (9):589-593.

Tekeli A, Kutlu HR, Celik L (2011). Effects of Z. Officinale and propolis extracts on the performance, carcass and some blood parameters of broiler chicks Current Research Poultry Science, 1 (1):12-23. 
Valiollahi MR, Rahimian Y, Rafiee A, Miri Y (2014). Effect use ginger (Zingiber Officinale), black pepper (Piper Nigrum L) powders on performance, some blood parameters and antibody titer against new castle vaccine on broiler chicks. European Journal of Zoological Research, (3): 61-66.

Wafaa BZ, Khadiga AA, Bakheit MD, Ahmed GM (2012). The effect of ginger root powder (Zingiber Officinale) supplementation on broiler chick's performance, blood and serum constituents. Online Journal of Animal and Feed Research,1 (6): 457-460.

Zhang G F, Yang Z B, Wang Y, Yang W R, Jiang S Z, Gai G S (2009). Effects of ginger root (Zingiber Officinale) processed to different particle sizes on growth performance, antioxidant status, and serum metabolites of broiler chickens. Journal of Poultry Science, 88 (10): 2159.

Zomrawi WB, Abdel-Atti KHA, Dousa BM, Mahala AG (2012). The effect of ginger root powder (Zingiber Officinale) Supplementation on broiler chick's performance, blood and serum constituents. Online Journal of Animal and feed research, 1 (6): 457-460.

Zomrawi WB, Abdel-Atti KHA, Dousa B M, Mahala AG (2013). The effect of dietary ginger root powder (Zingiber Officinale) on broiler chicks' performance, carcass characteristics and serum constituents. Journal of Animal Science Advances, 3: 42-47. 